\title{
Dünyada ve Türkiye'de Blok Zinciri Teknolojisi: Finans Sektörü, Dış Ticaret ve Vergisel Düzenlemeler Üzerine Genel Bir Değerlendirme*
}

\author{
Betül Altay Topcu $^{1 \dagger}$, Sevgi Sümerli Sarıgül ${ }^{2}$ \\ ${ }^{1}$ Kayseri Üniversitesi, Meslek Yüksekokulu, Pazarlama ve Dış Ticaret Bölümü, Kayseri, Türkiye (ORCID: 0000-0003-2044-4568) \\ ${ }^{2}$ Kayseri Üniversitesi, Meslek Yüksekokulu, Pazarlama ve Dış Ticaret Bölümü, Kayseri, Türkiye (ORCID: 0000-0002-3820-6288)
}

(Konferans Tarihi: 5-7 Mart 2020)

(DOI: $10.31590 /$ ejosat.araconf5)

ATIF/REFERENCE: Altay Topcu, B. \& Sümerli Sarıül, S. (2020). Dünyada ve Türkiye'de Blok Zinciri Teknolojisi: Finans Sektörü, Dış Ticaret ve Vergisel Düzenlemeler Üzerine Genel Bir Değerlendirme. Avrupa Bilim ve Teknoloji Dergisi, (18), 27-39.

$\ddot{O} z$

Endüstri 4.0’’n itici gücü olarak kabul edilen Blok Zinciri Teknolojisi, her bir sözleşme, işlem veya ödemenin birebir tanımlanıp, doğrulanıp, depolanıp paylaşılabilmesi için dijital olarak kaydedildiği ve imzalandığı bir teknoloji protokolüdür. Bu teknoloji, belirli bir merkezde yer alan sunucuları devre dışı bırakarak, taraflar arasında bilgi akışını sağlayan bilgisayarları birbirine bağlamaktadır. Ayrıca, bir ağdaki işlemlerin kesintisiz şekilde kaydedilmesine olanak vermektedir. Ağda yer alan her bir katılımcının kendisine ait bir hesap defterine sahip olması ve böylece tüm işlemlerini görebilmesi sağlanmaktadır. Her bir blok, bir önceki blok ile ilişkilendirilmiş ve şifreli bir referans ile korunduğundan ötürü güvenilirliği oldukça yüksek bir sistemdir. Bu kapsamda söz konusu uygulama ile sisteme kayıtlı ve ilgili taraflar arasında doğrudan transfer edilebilen belgeler oluşturulabilmektedir. Bu durumda genel olarak ortaya çıkabilecek güven, evrak akışındaki gecikmeler, aracılara olan gereksinim gibi sorunların üstesinden gelinebilecektir. Bu çalışmanın amacı, günümüzde birçok sektörde kullanımı yaygınlaşan Blok Zinciri Teknolojisi Uygulamaları'nın, dünyada bu teknolojiyi kullanan lider ülkeler ve Türkiye açısından değerlendirilmesidir. Çalışma bu teknolojinin Türkiye'de kullanıldığı alanların ve kaydettiği aşamanın tespit edilmesi açısından önem arz etmektedir. Dünya lider ülke uygulamaları incelendiğinde, ülkelerin bu teknolojinin kullanımında belirli bir aşamaya geldikleri, Türkiye'nin ise bu ülkelerin henüz gerisinde kaldığı gözlemlenmiştir. Türkiye'de özellikle dış ticaret alanındaki uygulamalar değerlendirildiğinde, bu uygulamaların proje bazında devam ettiği, ancak hayata geçirilemediği görülmektedir. Bu açıdan Türkiye'nin rekabet gücünün tesis edilebilmesi ve lider ülkeler arasında yer alabilmesi, hükümetin bu teknolojinin kullanıma yönelik teşvik ve uygulamalarını gerektirmektedir.

Anahtar Kelimeler: Bitcoin, Blok Zinciri Teknolojisi, Dijitalleşme, Vergi Düzenlemeleri.

\section{Blockchain Technology in the World and Turkey: A General Evaluation of the Financial Sector, Foreign Trade and Tax Regulations}

\begin{abstract}
One of the key elements of Industry 4.0 is the Blockchain application, a technology protocol in which each contract, transaction or payment is digitally recorded and signed for one-to-one identification, verification, storage and sharing. This technology connects computers that enable information flow between parties by disabling servers located at a particular center. It also allows continuous recording of transactions on a network. Each participant in the network has his own account book so that they can see all his transactions

Each block is a highly reliable system since it is associated with the previous block and protected by an encrypted reference. In this context, documents can be created that are registered to the system and can be transferred directly between the related parties. In this case, problems that may arise in general, delays in document flow, and the need for intermediaries can be overcome. The aim of this study was the widespread use today in many sectors Chain Block Apps Technology, a leading countries in the world using this technology and to evaluate in terms of Turkey. Our study is important in terms of determining the stage of the areas where the use of this technology in Turkey and save. When the world's leading countries examined practices of countries they come to a certain stage in the use of this technology, whereas Turkey has been observed that these countries still remain behind. Turkey, especially when assessing applications in the field of foreign trade, this practice has continued in some projects, but is seen not implemented. In this
\end{abstract}

\footnotetext{
${ }^{*}$ Bu makale International Conference on Access to Recent Advances in Engineering and Digitalization (ARACONF 2020) de sunulmuştur.
} 
respect can be established among the leading countries of Turkey's competitiveness, the government is required to promote the use of this technology and its applications.

Keywords: Bitcoin, Blockchain Technology, Digitalization, Tax Regulations.

\section{Giriş}

2009 yılında Bitcoin para biriminin piyasaya sunulması ile birlikte, Blok Zinciri Teknolojisi ortaya çıkmış ve büyük bir ilgi konusu olmuştur. Günümüzde internet üzerinden yapılan para transferi, insanların işlemlerini kısa sürede yapmasını sağlayan teknolojik imkânlardan biridir. Özellikle e-ticaretin gelişmesiyle, ürün ve hizmetlerin internet üzerinden farklı ödeme seçenekleriyle temin edilebilmesi yeni bir ekonomik düzenin ortaya çıkmasına neden olmuştur (Taş ve Kiani, 2018, 369). Blok zinciri kelimesini ilk kez dolaylı olarak, Satoshi Nakamoto 2008 yılında yayınladığı "Bitcoin: A Peer-to-Peer Electronic Cash System-Bitcoin: Eşler Arası Elektronik Nakit Sistemi” adlı makalesinde dile getirmiştir. Nakamoto (2008), blok zinciri kelimesini ele aldığ 1 makalesinde geçirmemiş olsa da, kripto paranın altında yatan bir teknoloji bileşenini, kriptografik olarak birbirine zincirlenmiş bir dizi veri bloğu olarak tanımlamıştır. Nakamoto, 2008 Kasım ayında "Cryptography Mailing List”de yayınladığı sayfa ile Bitcoin protokollerini yayınlamıştır. 2009 yılında yayınladığı Bitcoin’in ilk versiyonundan sonra, 2010 yılına kadar Bitcoin üzerinde geliştirmeler yapmıştır (coinkolik).

Dijital bir para birimi olarak kullanılan Bitcoin, birçok açıdan geleneksel para birimlerinden farklılaşmaktır ve birtakım avantajlara sahiptir. İşleyiş açısından en önemli özelliği, eşten eşe ödeme sistemine (peer-to-peer cash system) olanak vermesidir. Blok Zinciri Teknolojisi’nin işlem maliyetlerini önemli ölçüde azaltması ve işlem gerçekleşme zamanını kısaltması açısından önemli avantajlar sağlamaktadır. Ayrıca, Blok Zinciri Teknolojisi içerisinde en çok bilinen ve kullanılan dijital para birimi olması nedeniyle "dijital değişimin medyumu” olarak da adlandırılan Bitcoin'in oluşturulması, elde edilmesi, toplanması ve ticarette kullanımı elektronik olarak mümkün olmaktadır (Raiborn ve Sivitanides, 2015, 26-27).

Blok Zinciri Teknolojisi’nin ilk uygulaması olan Bitcoin, eşler arası teknolojiyi kullanarak merkezi bir otorite veya banka olmadan çalışır. İşlemlerin yönetimi ve Bitcoin'lerin dağıtımı toplu olarak ağ tarafından idare edilir. Bitcoin açık kaynaklıdır; tasarımı halka açıktır, kimse Bitcoin'e sahip değildir ve kontrol edilemez, herkes tarafından katılınabilir. Bitcoin kendine has özellikleri sayesinde diğer ödeme yöntemleri ile yapılamayan çok farklı ödemelerin yapılabilmesine olanak vermektedir (Bitcoin; Iansiti ve Lakhani, 2008, 4). Blok zinciri, tüm Bitcoin işlemlerinin dağıtılmış işlemleridir. Bu, tek bir kayıt veritabanı olmadığı anlamına gelir. Blok zincirinin dağıtılmış doğası da güvenliği sağlamaya yardımcı olur. Çünkü Bitcoin topluluğu, toplu olarak tüm işlemler üzerinde anlaşır, ödemeleri engelleyebilecek veya tersine çevirebilecek merkezi bir otorite yoktur. Ancak Blok Zinciri Teknolojisi sadece Bitcoin için değil diğer birçok alanda da uygulanabilir (Hampton, 2016).

Blok Zinciri Teknolojisi’nin dünyadaki ilk uygulamaları finans sektöründe uluslararası para transferi şeklinde gerçekleşmekle birlikte, kısa zamanda sağlık, gıda, gümrükleme, sigortalama ve taşıma gibi lojistik sektöründe, dış ticaret ve muhasebe alanında da görülmeye başlamıştır. Birçok sektörde inovasyonu tetikleyici bir teknoloji olarak kullanımı sağladığı maliyet, güven, şeffaflık ve hız gibi avantajlar nedeniyle son zamanlarda artış göstermiştir. Çalışmada, son zamanlarda tüm dünyada yakın ilgi gören Blok Zinciri Teknolojisi'nin çalışma prensibi ve dış ticarette kullanımı kavramsal olarak açıklanmıştır. Ayrıca bu teknolojinin dünyada ve Türkiye'de kullanım alanları değerlendirilmiştir. Bu çalışma, söz konusu uygulamaların değerlendirilmesi ile Türkiye'nin bu teknolojideki yerinin tespit edilmesi açısından önem arz etmektedir. Çalışma beş bölümden oluşmaktadır. Çalışmanın giriş bölümünün ardından ikinci bölümde Blok Zinciri Teknolojisi’nin kavramsal açıklamalarına yer verilmiştir. Üçüncü bölümde dış ticarette Blok Zinciri Teknolojisi'nin kullanım şekli değerlendirilmiştir. Dördüncü bölümde ise, dünyada ve Türkiye'de Blok Zinciri Teknolojisi uygulamaları üzerinde durulmuştur. Çalışma sonuç bölümü ile tamamlanmıştır.

\section{Blok Zinciri Teknolojisi’nin Çalışma Prensibi}

Çalışmanın bu bölümünde Blok Zinciri Teknolojisi'nin çalışma prensibi; bu teknolojinin ağ yapısı, uluslararası para transferinde kullanım şekli, özellikleri, kullanım alanları ve potansiyel yararları açısından değerlendirilmiştir.

\subsection{Blok Zinciri Teknolojisi’nin Ăg Yapısı}

Günümüzde internet üzerinden yapılan sosyal medya uygulamaları, e-mail programları, haberleşme ile ilgili yazılımlar, e-sağlık, e-devlet, e-gümrük uygulamaları, e-ticaret yapan siteler ve e-lojistik gibi farklı ihtiyaçlara yönelik çeşitli teknolojik uygulamalar aracılığı ile çeşitli alanlarda ve konularda veri transferleri yapılmaktadır. Bu transferlerin genellikle güvenlik düzeyleri düşüktür. Bu transferlerin dışında, daha değerli ve özel varlıkların transferi, dağıtık bir veri tabanı olan "Blok Zinciri Teknolojisi” ile yapılmaktadır. Bu teknoloji, sunduğu imkânlar ve çeşitlendirilebilir uygulamaları sayesinde yüksek düzeyde bir güvenlik ve verimlilik sağlamaktadır (Bakan ve Şekkeli, 2019, 2950).

Literatürde Blok Zinciri Teknolojisi'nin tek tip bir tanımı mevcut değildir ve çeşitli tanımlamaları bulunmaktadır. Bir tanımlamaya göre, Blok Zinciri Teknolojisi, işlem kayıtlarını bilgisayar ağları üzerinde zaman kaşesiyle tarihlenerek tarihçeleri ile birlikte geriye dönük olarak değiştirilemeyecek ve silinemeyecek biçimde birbirine bağlı bloklar halinde saklayan, istendiğinde ulaşılabilen, denetlenebilen, programlanmış sözleşmeleri yürütebilen Web'den farklı bir teknolojidir. Blok zinciri, dağıtık (merkezi olmayan) ve ortak bir veri kayıt sistemidir (Özalp, 2018, 293).

Bir diğer tanıma göre, Blok Zinciri Teknolojisi, uzlaşma (consensus) algoritmalarıyla birçok site, ülke ve/veya enstitü arasında kopyalanmış, paylaşılmış ve senkronize edilmiş bir veri yapısıdır. Ağda meydana gelen her olay, düğümlerde doğrulanmakta ve 
kaydedilmektedir. Blok zincirinde ilk başlangıç bloğuna "genesis blok" ismi verilir (Usta ve Doğantekin, 2017, 118-119). Her blok, kendinden önceki bloğun özüt (hash) algoritmasından geçirilmiş içeriğine sahiptir. Blok zincirine eklenen her yeni bloğun girdilerinden birisi, bir önceki bloğun özüt değeridir. Yani blok zincirinde depolanan tüm veriler "özüt" adı verilen şifrelerle korunmaktadır. Böylece sistemdeki bir işlemi değiştirmek isteyen kişi, geriye doğru tüm işlemlerin özüt sonucunu hesaplamak zorundadır. Bu işlem pratik olarak mümkün değildir, çünkü hesaplanan sonuçların tüm madencilerde de aynı olması gerekmektedir (Taş ve Kiani, 2018, 372).

Blok Zinciri Teknoloji'si ağ yapısı Şekil 1'de gösterilmiştir. Blok zinciri, internet üzerinde dağıtık yapıda çalışan çok hızlı, güvenilir ve rahat işleyen esnek bir teknoloje sahiptir. Web'in alternatifi olarak ifade edebileceğimiz blok zincirini açıklamak için Web'i bir firtına olarak kabul edersek Blockchain teknolojisi bir kasırga olarak ifade edilebilir.

Şekil 1. Blok Zinciri Teknolojisi Ăg Yapısı

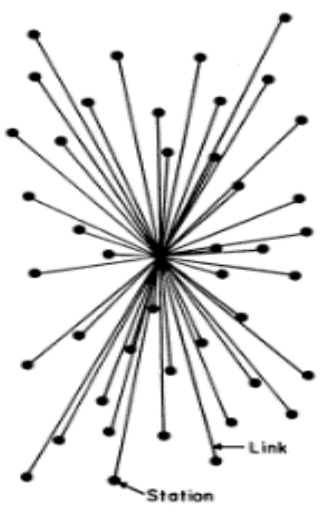

MERKEZI

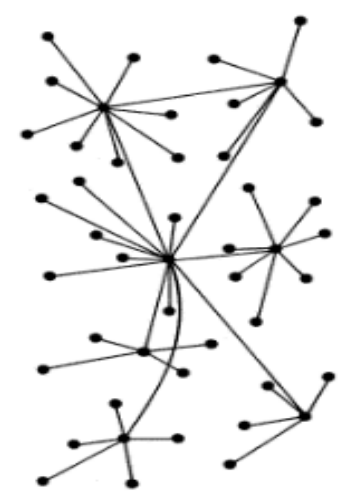

ÇOK MERKEZLI

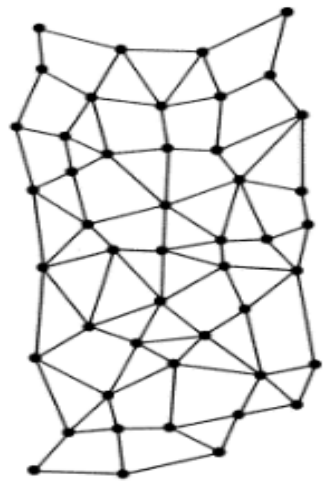

DAGITIK

Kaynak: Baran, 1964, 2; Özalp, 2018, 294.

\subsection{Blok Zinciri Teknolojisi’nin Uluslararası Para Transferinde Kullanım Şekli}

Kripto para birimi olan Bitcoin ile yapılabilecek en temel finansal işlem, taraflar arasında para transferi yapılmasıdır. Fiziksel para ile yapılan işlemlerde güvenlik önlemleri, paranın güvenli bir şekilde imal edilmesine ve kolay şekilde taklit edilememesine dayanmaktadır. Dijital para ile yapılan işlemlerde ise güvenlik önlemleri, yapılan işlemlerin dijital imzalar aracılığıyla sağlanmaktadır. Dolayısıyla A kişisi B kişisine para transfer ederken, yapılan işlemi kendi dijital imzasıyla imzalayarak güvenli hale getirmektedir (Ünsal ve Kocaoğlu, 2018, 56).

Blok Zinciri Teknolojisi, sınırlı veya belirlenmemiş sayıdaki eşler arası ağ aracılı̆̆ ile ağda bulunan katılımcıların yeni işlemleri girişi, yeni işlem bloklarını doğrulaması ve bunların (önceden onaylanmış işlemlerin) işlem bloklarını zincire eklemesi şeklinde çalışmaktadır. Blok Zinciri Teknolojisi ile uluslararası para transferi örneği Şekil 2'de verilmiştir.

Şekil 2. Blok Zinciri Teknolojisi Ile Uluslararası Para Transferi

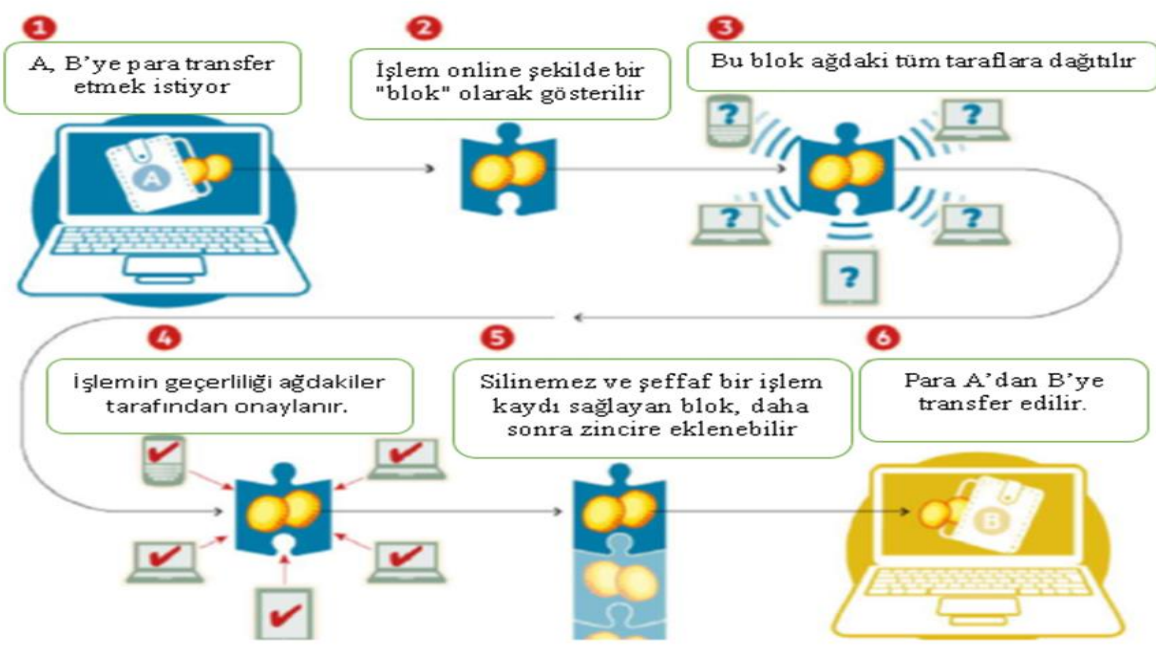

Kaynak: Crosby vd., 2016, 10; Wild, Arnold ve Stafford, 2015. 


\subsection{Blok Zinciri Teknolojisi’nin Özellikleri}

Blok Zinciri Teknolojisi'nin üç temel özelliği bulunmaktadır. Bunlar Şekil 3'de gösterilmiştir.

Şekil 3. Blok Zinciri Teknolojisinin Temel Özellikleri

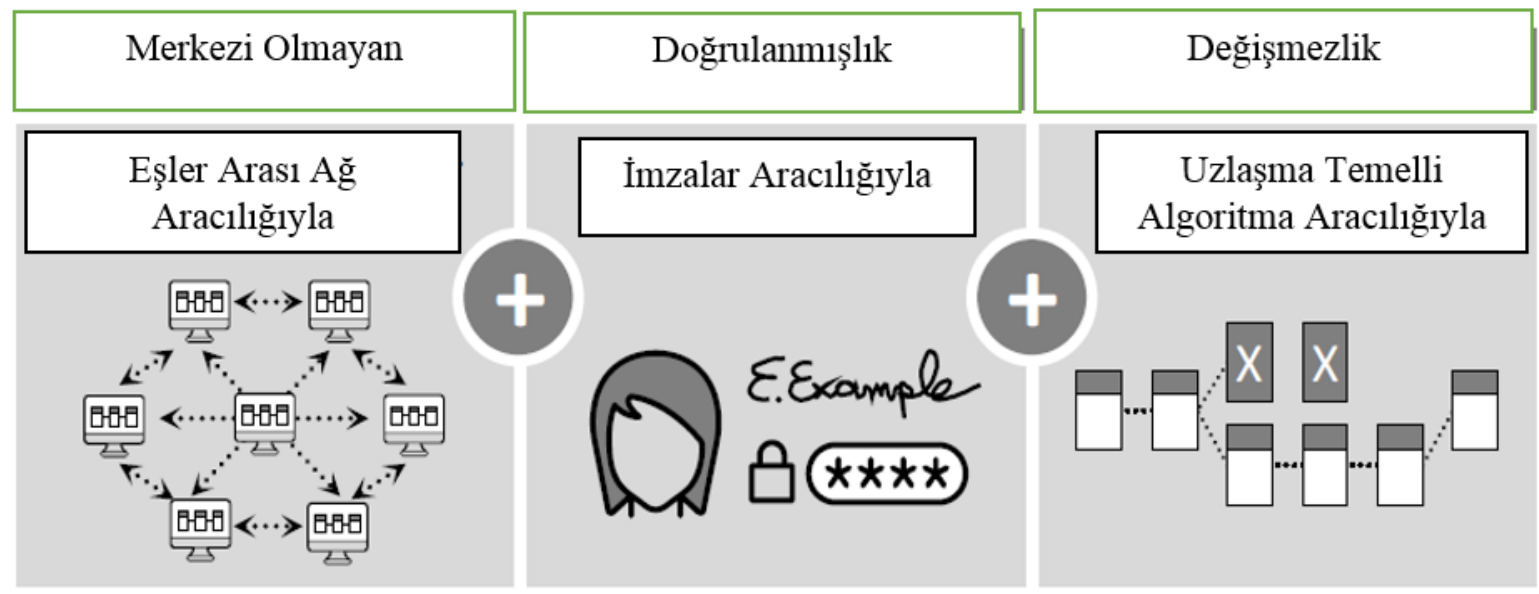

Kaynak: Hackius ve Petersen, 2017, 5.

Blok Zinciri Teknolojisi’nin üç temel özelliği; merkezi olmayan, doğrulanmışlık ve değişmezliktir. Merkezi olmayan özelliği; herhangi bir merkez veya kuruma bağlı kalınmadan kendi kendine işleyen, güvene dayalı bir alt yapı içerisinde ve sadece üyelik sistemi ile yürütülen bir ağ yapısına sahip olmak kastedilmektedir. Bu durum ağ üzerindeki merkezi otoriteyi ortadan kaldırarak katılımcıları doğrudan birbirine bağlar. Böylelikle ağdaki katılımcılar ağ üzerinde gerçekleşen işlemleri doğrudan görebilir ve onaylayabilir. Örneğin; bir üyenin gerçekleştirmiş olduğu bir hesap ya da ödeme işleminde, blok zincirinde yer alan ve eşler arası ağ olarak adlandırılan çok sayıda bilgisayar aracılığıyla işlem paylaşılır ve bunun sonucunda da ağda bulunan tüm üyeler yapılan bu işlemin birer kopyasını kendi kayıtlarında saklayabilirler.

Doğrulanmışlık özelliği, ağdaki tüm üyeler kendilerine ait özel şifrelere sahiptir ve ağ üzerinde hehangi bir işlemi gerçekleştirebilmek için bu özel şifreleri (digital imza) kullanırlar. Bu nedenle sadece şifreye sahip olan üyeler ağa giriş yapabilmektedirler. Dijital imzalar kullanıcıların özel anahtarlarıyla (Private Key) oluşturulmakta ve kullanıcılara ait genel anahtarlar (Public Key) kullanarak bu imzaları kontrol edilebilmekedir. Ancak üyeler isterse kimliklerini gizli tutabilmektedirler. Çünkü bu şifreler kişilerin gerçek dünyadaki kimlikleriyle ilişkilendirilmemektedir.

Değişmezlik özelliği ise, yazılımın uzlaşma tabanlı algoritmasından kaynaklanmaktadır. Bir veya daha fazla yapılan işlem yeni bir blok oluşturacak şekilde gruplandırılır. Ağın tüm üyeleri bloktaki işlemleri doğrulayabilmektedir. Eğer bir bloğun geçerliliği üzerinde fikir birliği sağlanamazsa o blok reddedilir. Benzer olarak eğer ki bir bloğun geçerliliği üzerinde fikir birliği sağlanırsa o blok zincire eklenir. Her blok için bir şifreleme karması oluşturulur. Her blok sadece kendi işlem kayıtlarını değil, aynı zamanda bir önceki bloğun karmasını da tutar. Bu bir zincire bağlanan bir blok bağımlılığı oluşturur. Blok zincirindeki işlemin geriye dönük olarak değiştirilmesi sadece ağ üyelerinin cihazlarının çoğunda yerel kayıtların yanı sıra zincirdeki her bloğun şifreleme karmasını da değiştirir (Hackius ve Petersen, 2017, 5-6).

\subsection{Blok Zinciri Teknolojisi’nin Kullanım Alanları ve Potansiyel Yararları}

2009 yılında ortaya çıkan Blok Zinciri Teknolojisi hayatın birçok alanına girmiştir. Finans dünyasının farkındalığı ve ilgisi ise 2014 yılında oluşmaya başlamıştır. Bu teknolojinin çıkış noktası para transferi olsa da finans dünyasının dışında dış ticaret, uluslararası transfer işlemleri, sigortacılık, tedarik zinciri yönetimi ve sağlık gibi birçok alanda kullanılmaktadır (Özalp, 2018, 310311).

Blok zincirinin, sistematik yapısı içerisinde uygulama ve diğer teknolojileri geliştirebilecek bir alt sağlamasından dolayı, pek çok sektör tarafından ilgi odağı haline gelmiştir. Ancak mevcut kullanılan sistemlerin işleyiş ve kayıtlama biçimleri blok zinciri için uygun olmayabilir. Bu teknolojiyi kullanım kararı vermeden önce kurumun, tekniğin, sürecin, durumun veya kişinin güçlü ve zayıf yönlerini belirlenmeli, iç ve dış çevreden kaynaklanan fırsat ve tehditleri saptanmalı ve detaylı analizler yapılmalıdır. Blok Zinciri Teknolojisi'nin kullanım alanları aşağıdaki gibi özetlenebilir (Özalp, 2018, 310-311; Zheng ve Xie, 2018, 363-365; Erözel Durbilmez ve Y1lmaz Türkmen, 2019, 34):

Finansal Araçlar: Finansal enstrümanlar (hisse senetleri, bonolar ve tahviller), Türev Araçları (future, opsiyonlar, swap ve forward işlemleri).

Kamu İle İlgili İşlemler: Tapu, arsa kayıtları, noter işlemleri, araçlarla ilgili bilgilerinin kayıtları, mevzuatlar, işletmelerin ticari kayıtları, vergi işlemleri, mahkeme kayıtları, suç kayıtları, adli tıp kayıtları, dijital pasaport, dijital kimlik, oylama, silah ruhsatları. 
Sağllk Ille İlgili Isşlemler: Sağlık kayıtları, doğum ve ölüm belgeleri

Özel Kayıtlar: Sözleşmeler, akıllı kontratlar, dijital imzalar, kişisel gps kayıtları.

Lisanslar: Patentler, lisanslar, telif hakları, domain (alan) adları, dijital kimlikler.

Dış Ticaret Ille İlgili Işslemler: Lojistik işlemleri, gümrük işlemleri, liman işlemleri, sigorta işlemleri.

Diğer: Fotoğraf, video ve ses kayıtları, sim kartları.

\subsection{Blok Zinciri Teknolojisi’nin Potansiyel Yararları}

Blok Zinciri Teknolojisi’nin potansiyel yararları stratejik, organizasyonel, ekonomik, bilgisel ve teknolojik olmak üzere beş ana grupta toplanarak Tablo 1'de açıklamaları ile birlikte incelenmiştir.

\section{Tablo 1. Blok Zinciri Teknolojisi'nin Potansiyel Yararlart}

\begin{tabular}{|c|c|}
\hline Stratejik & $\begin{array}{l}\text { - Şeffaflık: Ağdaki tüm kullanıcılar zincir içerisinde gerçekleşen tüm işlemleri eş } \\
\text { zamanlı olarak görebilmektedirler. Verilere erişim herkese açıktır. } \\
\text { - Dolandırıcılıktan ve Manipülasyondan Kaçıma: Saldırıların veya yetkisiz olarak } \\
\text { yapılan değişikliklerin fark edilmeden yapılması zordur. Bilgiler birden fazla } \\
\text { deftere kaydedildiği için dağıtılmıştır. } \\
\text { - Yolsuzluğun Azaltılması: Dağıtılmış defterler yoluyla yapılan depolama, } \\
\text { sistemdeki verilerin bozulmasını ve değiştirilmesini önler. }\end{array}$ \\
\hline Organizasyonel & $\begin{array}{l}\text { - Güvenin Artması: Kayıtların değiştirilememesi ve verilerin birden çok düğümle } \\
\text { doğrulanması sonucunda süreçteki kontrol artar ve bu durum sisteme olan güveni } \\
\text { arttırır. } \\
\text { - Şeffaflık ve Denetlenebilirlik: İşlemlerin geçmişinin takip edilebilmesi için birden } \\
\text { çok kayıt defterine ulaşılması ile denetim ve tutarlılık sağlanmaktadır. } \\
\text { - Tahmin Yeteneğini Arttırmak: Tüm tarih bilgileri geriye doğru izlenebildiğinden } \\
\text { bu durum tahmin yeteneğini arttırabilir. } \\
\text { - Kontrolün Arttırılması: Sistemde yer alan tüm bilgiler oy birliği ile kendi içinde } \\
\text { konrollü olarak kaydedildiğinden ötürü veri doğruluğu ve kalitesi yüksektir. }\end{array}$ \\
\hline Ekonomik & $\begin{array}{l}\text { - Maliyetin Düşürülmesi: Herhangi bir merkez veya kuruma gerek } \\
\text { duyulmadığından bir işlemin gerçekleştirilmesi veya doğrulaması için oluşan } \\
\text { maliyetler azaltılabilmektedir. } \\
\text { - Spam Iletilere Karşı Daha Fazla Esneklik ve DDOS Saldırıları: Sistem kendi } \\
\text { içinde yüksek düzeyde güvenlik sağladığı için siber saldırılar için mevcut sistem } \\
\text { içerisinden alınan önlemlerin maliyeti düşürülebilir. }\end{array}$ \\
\hline Bilgisel & $\begin{array}{l}\text { - Üstün Veri Kalitesi ve Verilerin Bütünlüğ̈̈: Sistem içinde saklanan bilgiler, fikir } \\
\text { birliği ile alındığı için yüksek veri kalitesine sahiptir. } \\
\text { - İnsan Hatalarını Azaltmak: Gerçekleştirilen işlemler ve bunların kontrolleri } \\
\text { otomatik olarak gerçekleştiğinden dolayı insan kaynaklı hatalar azalmaktadır. } \\
\text { - Bilgiye Ulaşmak: Bilgiler kolay ve hılıca erişilebilecek birden fazla yerde } \\
\text { saklanır. Böylece ağdaki mecut kişiler bu bilgilere kolaylıkla erişebilir. } \\
\text { - Gizlilik: Kullanıcılar şifreleme anahtarları aracılığıyla anonim olabilmektedirler. } \\
\text { Böylece ağdaki diğer kişilerin kendilerine ait kimlik bilgilerinin görüntülenmesini } \\
\text { önleyebilirler. } \\
\text { - Güvenilirlik: Sistemin özelliği sayesinde veriler birden fazla yerde saklanır. } \\
\text { Yalnızca ağda bulununlar fikir birliği yapıp, kabul ettiğinde bilgiler değiştirilebilir. }\end{array}$ \\
\hline Teknolojik & $\begin{array}{l}\text { - Esneklik: Sistem kötü niyetli davranışlara karşı dayanıklıdır. } \\
\text { - Güvenlik: Veriler merkezi olmayan, dağınık birden çok veri tabanında depolandı̆̆ } 1 \\
\text { için, verileri ele geçirmek, kötü niyetli işlemlerin fark edilmeden yapılması } \\
\text { mümkün değildir. } \\
\text { - Kalıcılık ve Değişmezlik: Veriler birden fazla dağınık defterlerde saklanır ve veri } \\
\text { bir blok zincirine yazıldıktan sonra değiştirmek veya silmek zordur. } \\
\text { - Azalan Enerji Tüketimi: Ağda kullanılan enerji tüketimi, artan verimlilik ve işlem } \\
\text { mekanizmaları ile azaltılabilir. }\end{array}$ \\
\hline
\end{tabular}

Kaynak: Ølnesa, Ubachtb ve Janssenb, 2017, 359; Potekhina ve Riumkin, 2017, 11-13.

\section{Dış Ticarette Blok Zinciri Teknolojisi’nin Kavramsal Çerçevesi}

Dış Ticaret işlemlerinde ihracatçı ve ithalatçı firmalar, nakliye, sigorta, gümrükleme firmaları ve bankalar gibi çok sayıda taraf ve bu tarafların çok sayıda gerçekleştirdikleri işlemler bulunmaktadır. Dış ticaret işlemlerinde yer alan aktörler arasında ilgili belgelerin 
eksiksiz bir şekilde hazırlanması, bu belgelerin kısa sürede ve güvenilir bir şekilde taraflara iletilmesi kritik bir öneme sahiptir. Bu çerçevede çıması olası problemlerin çözümü için blok zinciri uygulamaları ortaya çıkmıştır. Çalışmanın bu bölümünde uluslararası ticarette Blok Zinciri Teknolojisi’nin kavramsal çerçevesine yer verilmiştir.

\subsection{Uluslararası Ticarette Ödeme ve Blok Zinciri Teknolojisi Kullanımı}

Uluslararası ticarette en çok kullanılan ödeme yöntemlerinden birisi de akreditiftir. Akreditifi takiben açık hesap ödemesi, mal mukabili, vesaik mukabili ve peşin ödeme gelir. Açık hesap ödemeleri, ihracatçı açısından yüksek risk oluşturur. Malları teslim ettiğinde ihracatçı için ödemenin yapılması hayati önem taşımaktadır.

Klasik olarak yürütülen akreditif ile ödeme yöntemi akreditife konu tarafların çokluğu, hazırlanması gereken vesaikler ve bu vesaiklerin tek tek kontrol edilmesi, gönderilmesi ve takip edilmesinden ötürü karmaşık bir süreçtir. Akreditifli ödeme durumunda Blok Zinciri Teknolojisi'nin benimsenmesi ödeme sürecini, evrak yönetimini basitleştirip, maliyetleri düşürecektir. Şekil 4'de dış ticarette klasik akreditifli ödeme işlemi ve Şekil 5'de blok zinciri tabanlı akreditifli ödeme işlemi gösterilmişsir.

Şekil 4. Dış Ticarette Klasik Akreditifli Ödeme İ̧slemi

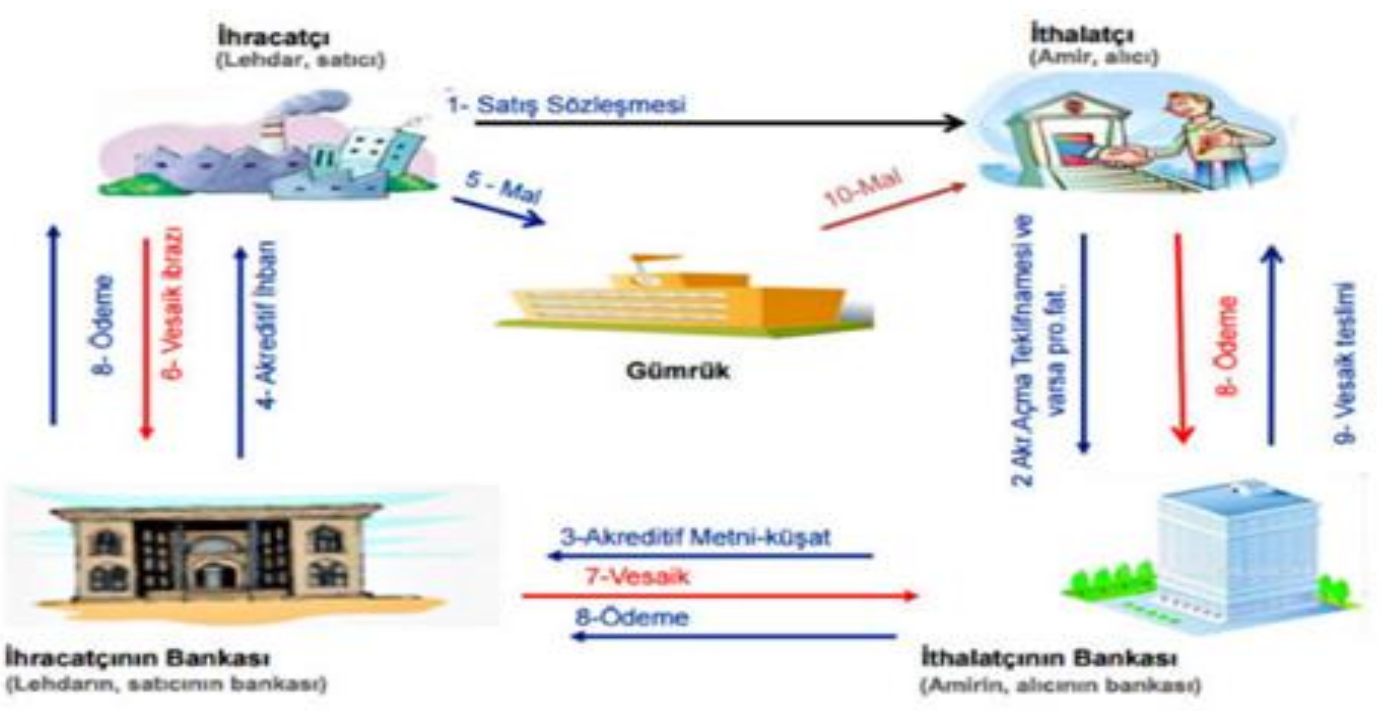

Kaynak: Gürsoy, 2016, 83.

Şekil 5. Dış Ticarette Blok Zinciri Tabanlı Akreditifli Ödeme İşlemi

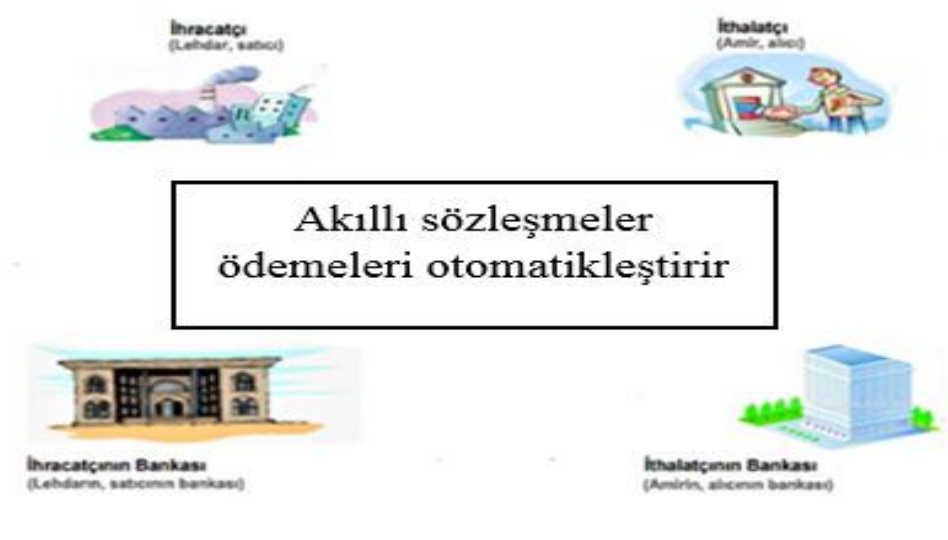

Kaynak: Yazarlar tarafindan oluşturulmuştur.

Blok zinciri uygulaması sayesinde finansman ve ödeme sürecinde, dış ticaret işlemleri ve bankacılık faaliyetleri dijitalleştirebilecek ve bu durum ödeme ve finansman yöntemlerinin yanı sıra nakit paraya erişimi de kolaylaştıracaktır. Böylece ticaret işlemlerini başlatmak ve yürütmek basitleşmiş olacaktır. Blok zinciri kullanımı, dış ticarete ilişkin vesaiklerin dijitalleştirilmesine izin verecektir. Böylece zamandan, maliyetten de tasarruf edilebilecektir. 
Blok zinciri tarafından desteklenen sınır ötesi ödemeler, işletmeler ve tüketiciler için önemli avantajlar sağlar. Deloitte tarafından yapılan araştırmaya göre uluslararası ödeme işlemlerinde Blok Zinciri Teknolojisi’nin kullanılması, işlem maliyetlerinde \%40\%80’lik bir düşüş sağlarken, (muhabir bankalara olan gereksinimin duyulmaması işlem maliyetlerinin düşmesini sağlamıştır), para transfer işlemleri tahmin 4 ile 6 saniye içerisinde gerçekleşebilmektedir (Khandaker, 2019).

\subsection{Günümüz Dış Ticaret Süreci ve Mevcut Problemler}

Tedarik zinciri, mal veya hizmetlerin, hammadde temininden nihai tüketiciye ulaşıncaya kadar geçen süreci tanımlar. Bu süreç, hammaddelerin tedariki, imalat ve montaj işlemleri, depoloma ve stok işlemleri, sipariş verme işlemleri ve ürünün dağıtım kanallarına sevkiyatının ve diğer dış paydaşların koordine edilmesini sağlayan ve yapılan faaliyetlerin yürütülmesi ve denetimini kapsayan bir zincirdir (Lai ve Cheng, 2016, 153). Bu zincirin etkili bir şekilde yönetilmesi işletmelere maliyetlerin azaltılması ve müşteri memnuniyetinin artırılması konularında avantajlar sağlamaktadır (Ungan, 2011, 308).

Uluslararası ticaret, literatürde genellikle mal, para ve vesaiklerin sınır ötesine transferi işlemidir. Mal ve hizmet, ihracatçıdan ithalatçıya gönderilirken, para da ithalatçıdan ihracatçıya transfer edilir. Vesaik işlemlerine gelince fatura, yükleme belgeleri, sigorta belgeleri, tercihli ticaret anlaşmalarında kullanılan muafiyet sağlayan belgeler, menşei belgeleri, garanti ve izin belgeleri ise ihracatçı ve ithalatçı arasında karşılıklı olarak transfer edilir. Günümüz klasik dış ticaret sürecindeki işlemleri 8 aşamada Şekil 6'daki gibi özetleyebiliriz.

\section{Şekil 6. Klasik Dış Ticaret Süreci}

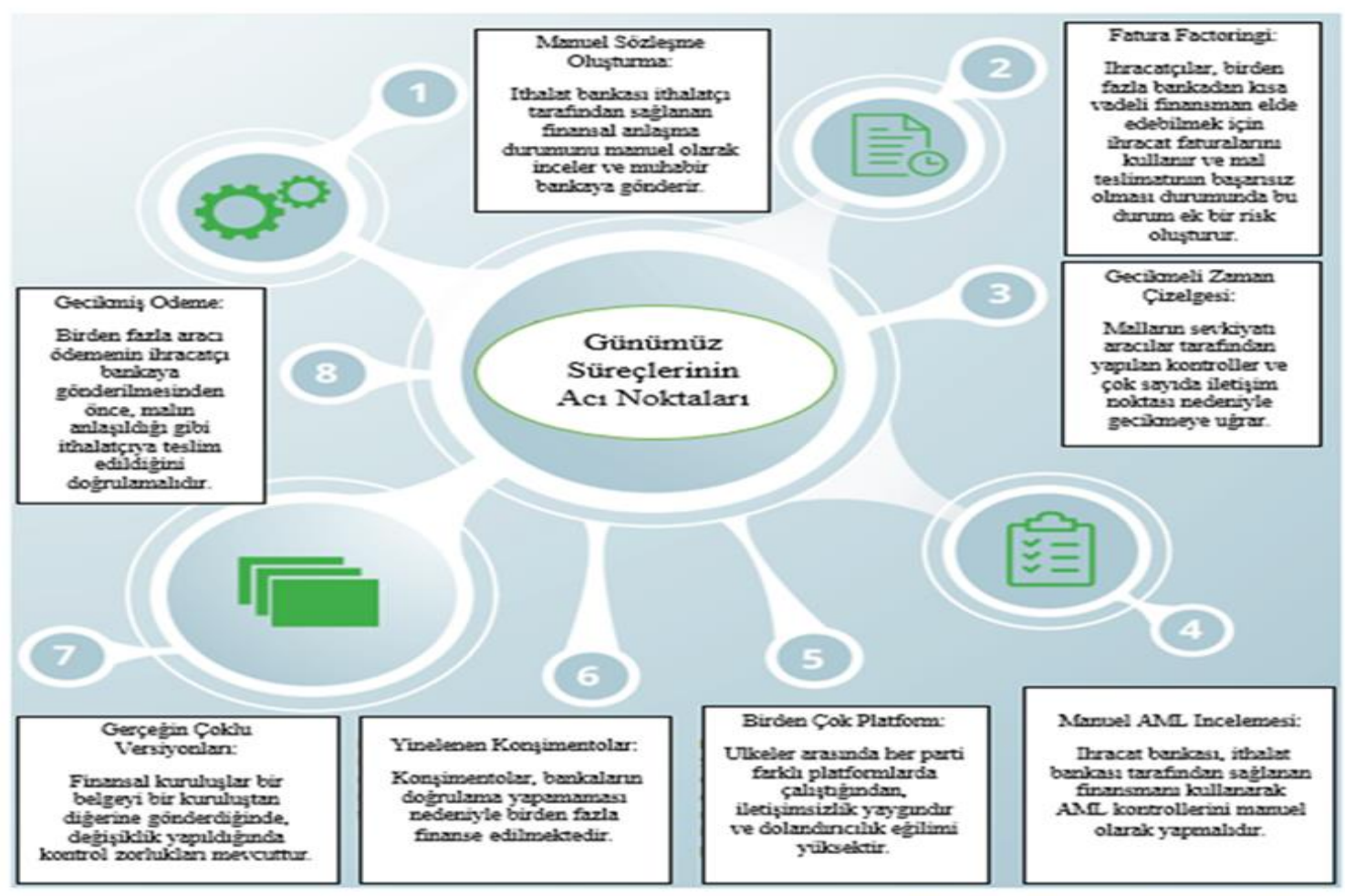

Kaynak: Deloitte.

Çok sayıda faktörün dış ticaret işlemleri sürecinde rol alması eşya, para ve evrak trafiğini karmaşıklaştırırken işlem maliyetlerini de artırmaktadır. Geleneksel tedarik zinciri sürecine ihracatçı ve ithalatçının dışında, gümrük müşavirlikleri, bankalar, lojistik firmaları, liman işletmeleri gibi oldukça fazla kişi ve kurumun taraf olması, sürecin işleyebilmesi için çok sayıda belgenin işleme konulması, basılı olan dokümanların kaybolma, yırtılma veya kopyalanma risklerinin bulunması önemli sorunlar arasında gösterilmektedir.

Dış ticaret işlemlerinde düzenlenen belgelerin doğru ve geçerli olması gümrükleme süreci için çok önemlidir. Dokümanların kontrolü ve yönetimine duyulan ihtiyaç, aracıların fazla olması sebebiyle işlem maliyetlerinin artmasına neden olmaktadır. Ayrıca tedarik zinciri sürecinin şeffaf olmaması, ihracatçı ile ithalatçı arasındaki mal veya hizmetin gerçek piyasa değerinin ve yapılan satışın kanunlara uygunluğunun tespitinin yapılmasını zorlaştırmaktadır (Marr, 2018; Özyüksel ve Ekinci, 2020, 89). Blok zincirinde, işlemlerin geriye doğru takip edilebilmesi ve özel blok zinciri anahtar altyapısının kullanılarak sadece izin verilen kişilerin işlem yapabilmesi bu bahsi geçen konularda olası problemleri ortadan kaldırabilecektir. 


\subsection{Blok Zinciri Teknolojisi ile Dış Ticaretin Şekillenmesi}

Blok Zincir Teknolojisi gerçek zamanlı bir yazılımdır. Dijital paranın, finansal varlıkların ve diğer dijital belgelerin iki ya da daha fazla kişi arasında geçişini anlık takip ve kaydetme imkânı tanımaktadır. Blok zincirinin dış ticaret iş sürecine entegre edilmesi ile ilgili çok sayıda saha çalışması yapılmaktadır. Blok Zinciri Teknolojisi ile dış ticaret süreci 8 aşamada Şekil 7'de gösterilmiştir. Dış ticaret süreçlerinde Blok Zinciri Teknolojisi'nden gümrük işlemlerinde ve tedarik zinciri yönetiminde faydalanıldığında Şekil 7'de gözüktüğü üzere Blok Zinciri Teknolojisi'nin aracısız işlem yapabilme veya aracıları en aza indirme olanağı ve belgelerin dijital ortamda güvenilir ve şeffaf bir şekilde kaydedilmesine imkân tanıması gibi çözümler getirebileceği görülmektedir. Bu kapsamda Blok Zinciri Teknolojisi'nin tedarik zinciri yönetimine katabileceği değerleri; işlem maliyetlerinin düşürülmesi, işlem sürelerinin kısalması ve olası müdahalelerin azaltılması, şeffaflığın ve izlenebilirliğin artırılması şeklinde belirtmek mümkündür.

\section{Şekil 7. Blok Zinciri Teknolojisi ile Dış Ticaret Süreci}

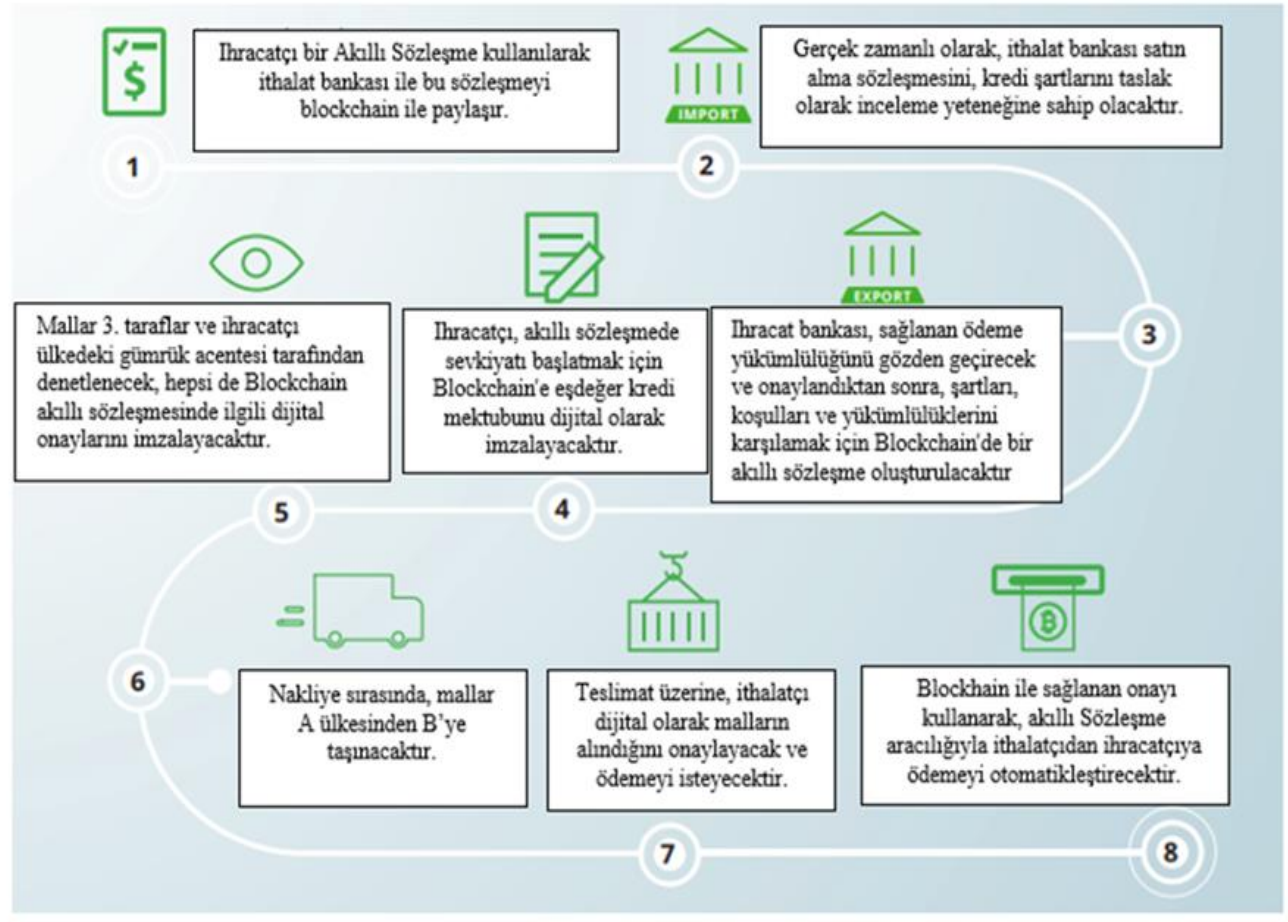

Kaynak: Deloitte.

Bu durumu bir örnekle açıklamak gerekirse; ABD'de bir paketleme malzemesinin sevkiyat süresi, ABD'den başka bir üretim hattına geçerken sevkiyat süresinin Blok Zinciri Teknolojisi ile \%40 oranında azaldığı ve çok düşük bir maliyetle işlemin tamamlandığı belirtilmiştir. Başka bir örnekte ise geleneksel uluslararası ticaret süreçlerinin evraklar bazında olduğu, bir ürünün Kenya'dan Hollanda'ya ihraç sürecinde yaklaşık $25 \mathrm{~cm}$. kalınlığında kâğıt doküman oluştuğu, sürece 30'dan fazla kurumun ve 100 'den fazla insanın taraf olduğu ve söz konusu işlemde, ürünün üreticiden tüketiciye ulaşmasının 34 gün sürdüğü, 10 gün boyunca dokümanların sisteme işlenmesinin beklendiği, bu sırada kritik öneme sahip bir belgenin kaybolduğu belirtilmiştir. Söz konusu örnekler uluslararası ticaret işlemlerinin hem süre açısından hem de doküman yönetimi anlamında birtakım çözümlere ihtiyaç duyulduğunu göstermektedir (Özyüksel ve Ekinci, 2020, 90).

\section{Dünyada ve Türkiye'de Blok Zinciri Teknolojisi Uygulaması}

Çalışmanın bu bölümünde, öncelikli olarak, dünyada bazı ülkelerin kripto para ve blok zincirine bakış açıları incelenmiştir. Daha sonra bu teknolijinin kullanım alanları dünya ülkeleri ve Türkiye açısından değerlendirilmiştir.

\subsection{Dünyada Bazı Ülkelerin Kripto Para ve Blok Zinciri Teknolojisi’ne Bakış Açıları}

Tablo 2'de Türkiye'de dahil olmak üzere dünyada bazı ülkelerin kripto paralara ve Blok Zinciri Teknolojisi'ne bakış açıları verilmiştir. 
European Journal of Science and Technology

Tablo 2. Dünyada Bazı Ülkelerin Kripto Para ve Blok Zinciri Teknolojisi Yaklaşımları

\begin{tabular}{|c|c|c|}
\hline Ülkeler & Kripto Para & Blok Zinciri \\
\hline Çin & Olumsuz & Olumlu \\
\hline Hindistan & Olumlu & Olumlu \\
\hline Singapur & Tarafsız & Olumlu \\
\hline Türkiye & Tarafsız & Olumlu \\
\hline Fransa & Tarafsı & Olumlu \\
\hline Avusturya & Tarafsız & Olumlu \\
\hline Kanada & Tarafsız & Olumlu \\
\hline Japonya & Olumlu & Olumlu \\
\hline İngiltere & Tarafsı & Tarafsiz \\
\hline Rusya & Olumsuz & \\
\hline
\end{tabular}

Kaynak: Erözel Durbilmez ve Y1lmaz Türkmen, 2019, 37.

Tablo 2'de görüldüğü gibi, Çin ve Rusya kripto paralar ile yapılan işlemlere olumsuz bakan ülkelerdir. Bu ülkelerde kripto paralara karşı yasaklamalar ve yaptırımlar uygulanmaktadır. Singapur, Türkiye, Fransa, Avusturya, Kanada ve İngiltere kripto paralar ile yapılan işlemlere karşı net bir bakış açısı ortaya koymayan, başka bir ifadeyle tarafsız kalan ülkelerdir. Ayrıca Hindistan ve Japonya kripto paralara karşı olumlu tavır sergilemektedir. Tablo 2 ülkelerin blok zinciri kullanımı yaklaşımları açısından değerlendirildiğinde, ülkelerin geneli blok zinciri ile yapılan işlemlere olumlu bakmaktadır. Dolayısıyla Çin, Hindistan, Türkiye, Fransa, Avusturya, Kanada, Japonya ve İngiltere Blokchain teknolojisinin kullanımına ilişkin araştırma grupları ve kurumlarını oluşturan ve bu konuda çalışmalar yapan ülkelerdir.

\subsection{Dünyada Blok Zinciri Teknolojisi Uygulaması}

2018 ve 2019 yıllarında geneli AB'ye üye olan toplamda Avrupa'da 30 ülke, Avrupa Blockchain Ortaklı̆̆ı'nı (European Blockchain Partnership-EBP) oluşturan bir deklarasyon imzalamışlardır. Bu deklarasyon ile ülkeler, sınır ötesi dijital kamu hizmetlerinin sunumunu destekleyecek bir Avrupa Blockchain Hizmetleri Altyapısı (European Blockchain Services InfrastructureEBSI) kurulması konusunda işbirliği yapmayı kabul etmiştir. Bu altyapı, yüksek güvenlik ve gizlilik standartlarına sahiptir. Bu deklarasyonu imzalayan ülkeler şunlardır: Almanya, Avusturya, Belçika, Bulgaristan, Çek Cumhuriyeti, Danimarka, Estonya, Finlandiya, Fransa, Güney Kıbrıs, Hırvatistan, Hollanda, İngiltere, İrlanda, İspanya, İsveç, İtalya, Letonya, Lihdenştayn, Litvanya, Lüksemburg, Macaristan, Malta, Norveç, Polonya, Portekiz, Romanya, Slovakya, Slovenya ve Yunanistandır. Üye ülkelerin içinde İngiltere, Norveç ve Lihdenştayn dışında hepsi AB üyesidir. Bu ortaklık, Avrupa'nın Blok Zinciri Teknolojileri'nin geliştirilmesi ve yaygınlaştırılması açısından atılan önemli bir girişim olarak görülmektedir (European Commission, 2018). Bu ortaklık Avrupa genelinde bir blok zinciri düğümleri ağı olarak tasarlanmıştır (Blockchain Türkiye Platformu, 2020).

Dünyada uygulanan para sistemleri sürekli olarak değișime uğramaktadır. Finansal sistem, eski takas sisteminden nakitsiz ödeme sistemlerine kadar gelişmiş ve değişiklikler geçirmiştir. Şu anda birçok ülke; ödeme sistemlerine giren, onlara yatırım yapan ve işlemlerini güvenli bir şekilde yapabilmek için Blok Zinciri Teknolojisi'ni benimseyerek, bu teknolojiyi pratik bir teste tabi tutmuş̧ur. Dünyada Blok Zinciri Teknolojisi'nin lideri ilk 10 ülke; Avustralya, Çin, Japonya, Dubai, Malta, İsviçre, ABD, Estonya, İngiltere ve Singapur'dur (Sharma, 2019). Bu ülkelerin bu teknolojide geldikleri aşamalar aşağıdaki gibi özetlenebilir (Sharma, 2019; Partz, 2018; Aktaş, 2018, 27; Xi Xu, 2017, 854; Boucher, 2017, 18):

Avustralya, Bitcoin ve kripto para birimleri kullanılarak yapılan tüm işlemlerde vergileri kaldırmıştır. Avustralya Menkul Kıymetler Borsası (ASX), Blok Zinciri Teknolojisi’ni, iki yıllık test döneminden iki yıl sonra tamamen kabul edeceğini duyurmuştur. Çin ekonomisinde bankacılık konsorsiyumları, Blok Zinciri Teknolojisi'ni kullanmaya başlamıştır. En iyi kripto para birimini ve Qtum, TRON, NEO, VeChain ve diğerleri gibi akıllı sözleşme platformlarını aktif olarak desteklemektedir. Diğer taraftan Çin Halk Cumhuriyeti Ekim 2017 itibariyle uygulamaya koyduğu "Gachain" kamusal blok zinciri teknolojisi ile vergileme ve e-fatura sistemini devreye almıştır. Bu sayede vergi tahsilatının hızlandırılması ve vergi kaçaklarının önlenmesi amaçlamaktadır. Japonya, diğer ülkelere nazaran Bitcoin ve kripto para birimlerine adaptasyonunu daha önce sağlayan ülkelerden biridir. Japonya'daki bazı perakende mağazaları Bitcoin ile yapılan alışverişleri kabul etmektedir.

Dubai, dünyanın en zengin ve en teknolojik ülkelerinden biri olarak bilinmektedir. Dubai, Belçika ile Abu Dabi Limanından yapılan sevkiyatların görünürlüğünü ve izlenebilirliğini arttırmak için Blok Zinciri Teknolojisi'nin kullanımına yönelik olarak ortaklık anlaşması yapmıştır. Dubai hükümeti tarafından, tüm veri ve belgelerin birleştirilerek Blok Zinciri'ne eklemek için 2020 yılı son tarih olarak belirlenmiş̧tir. Malta, kripto para birimlerinin bir değişim aracı olarak kullanılmasında kendisini küresel bir lider olarak konumlandırmıştır. İsviçre'deki Zug şehri, dünyanın en iyi blok zinciri şirketlerine ev sahipliği yapmaktadır. Zug, dünyanın önde gelen blok zinciri ekosistemini oluşturmayı amaçlayan ve kâr amacı gütmeyen Kripto Vadisi Derneği’ne (Crypto Valley AssociationCVA) ev sahipliği yapmaktadır.

$\mathrm{ABD}$, Bitcoin ve diğer sanal para birimleri ile ilgili faaliyetlerin vergilendirilmesi ile ilgili düzenlemeler yapmıştır. Bu düzenlemelere göre, Bitcoin madenciliğinden elde edilen kazançlar vergiye tabidir. ABD sınır kontrolü işlemleri, fikri mülkiyet haklarının korunması ve serbest ticaret anlaşması kapsamındaki ticarette eşyanın menşeinin izlenmesinde blok zincirine dayalı çözüm sistemlerini test etmektedir. Estonya hükümeti, bazı hizmetleri Blok Zinciri Teknolojisi’ni kullanarak dijital hale getirmiştir. Örneğin Estonya hükümeti, vatandaşların ilaç reçetelerini alabilmeleri, oy kullanabilmeleri, parasal işlemlerini kayıt altına alabilmeleri, 
vergilerini ödeyebilmeleri ve yaklaşık üç bin diğer dijital servise erişebilmeleri için denemelerde bulunmuştur. İngiltere hükümeti birçok yönden Blok Zinciri Teknolojisi'ni benimsemektedir. İngiltere'deki bu sistem, kimlik hırsızlığı ve yavaş finansal hizmet sorunlarını geliştirme potansiyeline sahiptir. İngiltere bu teknolojiyi, gıda endüstrisi ve hükümet belgelerinin arşivlere kaydedilmesinde yoğun olarak kullanmaktadır. Singapur, dijital defter teknolojisini kullanarak sınır ötesi ödemeleri desteklemektedir. Sigorta şirketleri akıllı sözleşmeler kullanmaktadır ve güvenli bir sağlık veri sistemi oluşturmaya çalışmaktadır.

Dünyada Blok Zinciri Teknolojisi'nin kullanımına yönelik bazı ülkeler açısından ilgili mevzuatlar Tablo 3'de gösterilmiştir.

Tablo 3. Blok Zinciri Teknolojisi’nde Vergisel Düzenlemelere İlişkin Ülke Uygulamaları

\begin{tabular}{|c|c|}
\hline Ülkeler & İlgili Mevzuat \\
\hline ABD & $\begin{array}{l}\text { Bir yıldan fazla süre elde tutulup sonrasında satılan kripto paralar sermaye kazançları vergisine } \\
\text { tabidir. Uygulanacak vergi oranları da kazancın miktar ve türüne göre } \% 15 \text { ile } \% 20 \text { arasında } \\
\text { değişebilmektedir. Bir yıldan az süre için ise } \% 25 \text { den başlayan normal gelir vergisine tabidir. } \\
\text { İşlem } 600 \text { Doların altında ise herhangi bir vergi yükümlülüg̈ü bulunmamaktadır. }\end{array}$ \\
\hline Avustralya & $\begin{array}{l}\text { Bitcoin veya kripto paralarla yapılan alım ve satımlar barter işlemi gibi değerlendirilip } \\
\text { vergilendirilmektedir. Şirketler, kurumlar vergisi ile işlem vergisine tabi olmaktadır. Bireysel } \\
\text { yatırırımcılar için } 10.000 \text { Avustralya Doları ve altında kripto para ile yapılan mal ve hizmet } \\
\text { alımları gelir ve tüketim vergilerinden muaftır. } 1 \text { Temmuz } 2017 \text { 'den itibaren Kripto paraların alım } \\
\text { ve satım işlemleri, mal ve hizmet işlem vergisinden muaf tutulmuştur. }\end{array}$ \\
\hline Almanya & $\begin{array}{l}\text { Kripto para alım ve satım işlemleri neticeside oluşan kârın } 800 \text { Euro'luk kısmı vergi istisnasına } \\
\text { tabidir. Bu tutarı aşar ise spekülatif kazanç kapsamında } \% 25 \text { oranında vergiye tabi tutulur. Kripto } \\
\text { para alım ve satımı işlemleri ise katma değer vergisinden muaf tutulmuştur. }\end{array}$ \\
\hline Güney Kore & $\begin{array}{l}\text { Ülkedeki mevcut vergi mevzuatı kripto paralar ile yapılan işlem ve sağlanan kârın nasıl } \\
\text { vergilendirileceğini düzenleyememektedir. }\end{array}$ \\
\hline Hollanda & $\begin{array}{l}\text { Bitcoin ile işlem yapan şirketler barter sözleşmesi esaslarına tabidir. Mükellefler, kripto paranın } \\
\text { işlem gördüğü tarihe esas ülke parası cinsinden hesaplanan değer üzerinden kurumlar vergisi ve } \\
\text { diğer vergileri öderler. Bireysel yatırımcılar ise elde ettikleri kâr üzerinden gelir vergisi } \\
\text { ödemektedirler. }\end{array}$ \\
\hline İngiltere & $\begin{array}{l}\text { Kripto para ile yapılan işlemler katma değer vergisinden istisnadır. Bu işlerle uğraşanlar \%20 } \\
\text { oranında kurumlar vergisi ödemek zorundadır. Bireysel yatırımcılar alış ve satış sonrası sağlamş } \\
\text { oldukları kâr üzerinden sermaye kazanç vergisi öderler. Yıllık kazanç miktarı } 11.300 \text { Sterlin ise } \\
\text { vergiden istisna tutulur. Evli çiftlerde ise bu tutar eşler ayrı ayrı hesaplandığından ötürü toplamda } \\
22.600 \text { Sterlin istisna tutarına ulaşıłlmaktadır. Yılllk kazanç tutarı } 45.200 \text { Sterlini aşıorsa kâra } \\
\text { bakılmaksızın vergi mükellefi olmak ve gelir vergisi ödemek zorundadırlar. }\end{array}$ \\
\hline İsviçre & Bireysel olarak yaplan birçok işlem sermaye kazançları vergisinden muaftır. \\
\hline Japonya & $\begin{array}{l}1 \text { Temmuz } 2017 \text { 'den itibaren Japonya'da bitcoin alan yabancı yatırımcılardan tüketim vergisi } \\
\text { alınmamaktadır. Mükellefler alım ve satım neticesinde elde ettikleri kâr üzerinden \%15-\%55 } \\
\text { arasında değişen oranlarda vergi ödemektedirler. }\end{array}$ \\
\hline Kanada & $\begin{array}{l}\text { Ticari işletmeler tarafindan kripto para işlemi yapılırsa barter anlaşması gibi değerlendirilip net } \\
\text { kazanç üzerinden kurumlar vergisi ve katma değer vergisine tabi olmaktadır. Bireysel yatırımcılar } \\
\text { için ise elde edilen kazançların \%50'si vergiden muaf tutulmaktadır kalan matrah ise normal vergi } \\
\text { tarifesi üzerinden vergilendirilmektedir. Ancak sürekli alım satım işlemi yapılıyorsa bu faaliyetler } \\
\text { ticari olarak değerlendirmektedir. }\end{array}$ \\
\hline Türkiye & 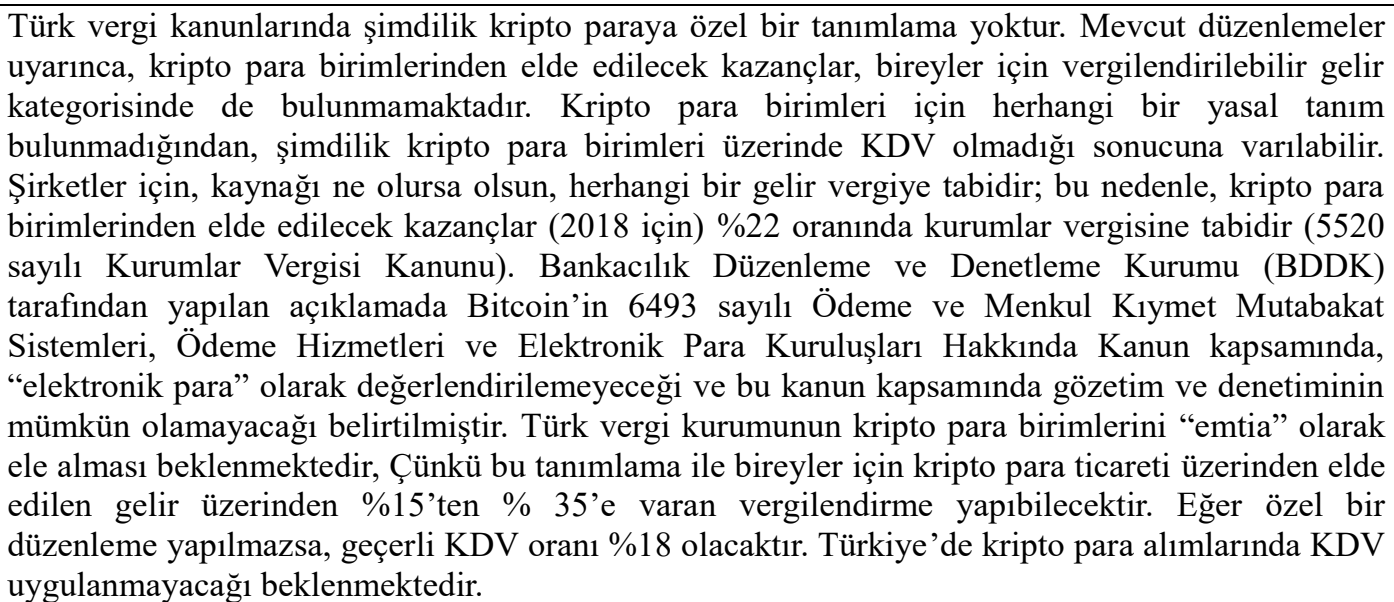 \\
\hline
\end{tabular}

Kaynak: COINTURK, 2018; Peaster, 2018; Zuckerman, 2018; Helms, 2018; Barry, 2018; Baktaş, 2018'den yararlanılarak yazarlar tarafindan oluşturulmuştur. 


\subsection{Türkiye'de Blok Zinciri Teknolojisi Uygulaması}

Türkiye ekonomisinde, 2019-2023 dönemini kapsayan 11. Kalkınma Planı'na göre, kurumsal açıdan güçlü bir finans sektörünün oluşması için finansal araç çeşitliliğine gidilecektir. Bu çerçevede Blok Zinciri tabanlı dijital Merkez Bankası parası uygulamaya konulacaktır. Bu uygulama ile birlikte fintech ekosisteminin Türkiye'de gelişmesine ve uygulanmasına yönelik olarak çalışmalar yapılacaktır (Ulukan, 2019). Türkiye Bilişim Vakfı tarafından, 8 Haziran 2018 tarihinde Blok Zinciri Teknolojisi'nin Türkiye'de kullanımının artırılması, faydalarının araştırılması ve stratejik hedeflerin belirlenmesi gibi nedenlerle, Blok Zinciri Türkiye Platformu (BCTR'yi) oluşturulmuştur. Bu platform Türkiye'de sürdürülebilir blok zinciri ekosistemi oluşturarak, bu teknoloji ile yapılan işlemlerdeki zorlukların giderilmesi hedeflenmektedir (Türkiye Bilişim Vakfı, 2019).

Ülkemizde finansal servislerle ilgili yenilikleri yakından takip eden, 1990 yılında 13 kamu ve özel bir türk bankasının ortaklığıla kurulan Bankalararası Kart Merkezi (BKM) Blok Zinciri Teknolojisi'ni birden çok alanda kullanmaktadır. Dijital kimlik, akıllı sözleşmeler, dağıtık kayıt defteri konularında blok zinciri temelli çalışmalar yapan BKM, bu kapsamda bir teknoloji şirketi olan Ankara merkezli T2 Software ile "keklik" adında bir şifrelenmiş para birimi geliştirmişlerdir. Deneysel olan bu projeye 200 özel kullanıcı erişim yapabilmekte, kullanıcılar mobil cihazlarda çevrimdışı olarak da çalışabilen P2P ile para transferi ve mağazalardan ürün satın alıp ödeme gibi işlemler yapabilmektedirler. Banka ve diğer hava yolu şirketlerinden bağımsız bir mil programı sunan Global Miles Kasım 2016'dan beri Blok Zinciri Teknolojisi'ni kullanmaktadır. Sanal birer varlık olan havayolu millerini ethereum blok zinciri altyapısıyla tamamen dijital bir varlık haline getiren Global Miles ekibi, transfer işlemini de bu altyapı üzerinde güvenli bir şekilde yapmaktadır (Demirel, 2017).

Akbank, uluslararası para transferinde Blok Zinciri Teknolojisi’ni kullanarak şeffaflık sağlayan, işlem zamanını kısaltan, maliyetleri düşüren çözümler üreten Ripple ile anlaşan ilk Türk bankası olmuştur. 29 Haziran 2017'de gerçekleşen anlaşma sonucunda Akbank, Ripple ile iş ortaklığına girmiştir. Akbank, Silikon Vadisi’nde faaliyet gösteren Ripple ile finans dünyasında çığır açan Blok Zinciri Teknolojisi'ni kullanmaya başlamıştır. Akbank, Almanya'da işlemlerini devam ettiren iştiraki Akbank AG üzerinden ödemeleri kapsayan bir pilot çalışma başlatmıştır (COINTRAL, 2019).

İstanbul Takas ve Saklama Bankası AŞ (Takasbank), Blok Zinciri Teknolojisi uygulamasını hayata geçirmiştir. Blok Zinciri Teknolojisi ile dayanağı fiziksel altın olan ve dijital bir varlığa çevrilebilen, zaman kısıtlaması olmaksızın altının kişiden kişiye transferine imkân tanıyan ve marka adı "BİGA Dijital Altın"olan bir sistem kurulmuştur (Yavuz, 2019). Türkiye'de kadınların da Blok Zinciri Teknolojisi'nde yer alabilmesi için Başak Burcu Yiğit ile Ebru Güven "Blockchain Women” adlı bir platform kurmuştur. Bu platformun amacı kadınların blokzincir ekosistemindeki varlığını artırmak, farkındalık yaratmak ve bilgi paylaşımıdır (bfmedia, 2019).

Borsa İstanbul'un internet sitesinden yaptığı açıklamaya göre, Blok Zinciri Teknolojisi kapsamında dünyada birçok farklı senaryo üzerinde çalışılırken, Türkiye'de finans kurumları arasındaki iş akışlarında kullanılan ilk blok zinciri projesi Borsa İstanbul tarafından hayata geçirilmiştir. Borsa İstanbul bilişim teknolojileri ekibince hazırlanan söz konusu blok zinciri projesiyle Borsa İstanbul, Takas İstanbul ve Merkezi Kayıt İstanbul'un elektronik başvuruya ait müşteri veri tabanında yer alan bilgiler senkronize hale getirilmiştir. Know Your Customer (KYC) konsepti ile hazırlanan projede, belirtilen veri tabanına yeni müşteri bilgisi eklenmesi, mevcut bilgilerin değiştirilmesi ve doküman yönetimi blok zinciri ağı üzerinden gerçekleştirilecektir. Böylece veri tabanına bilgi girişindeki olası hataların önüne geçilerek hızlı, güvenilir ve şeffaf bir platformun oluşması sağlanmıştır (NTV, 2018).

Türkiye'de konsorsiyumun başını çeken Güler Dinamik Gümrük Müşavirliği şirketi ve ulusal yazılım şirketi ATEZ tarafından Hyperledger Fabric platformu üzerinden ve IBM'nin teknoloji desteğiyle geliştirilen projede, Fransa'nın Lyon kentinden Manisaya ihraç edilecek bir eşyanın ticari ve finansal takibinin yapılması hedeflenmektedir (Aktaş, 2018, 27). Bu, eşten eşe ağların birbirine bağlandığı ve tedarik zincirinin yönetildiği Türkiye'nin ilk ve en önemli girişimi olacaktır. Bu uygulama, IBM Blok Zinciri Platformu üzerinden ürünün tedarik aşamasından teslimatına kadar geçen sürede gerçekleşecektir. Bu proje sayesinde Blok Zinciri Teknolojisini hatasız, güvenilir, şeffaf ve hızlı bir şekilde bu platform üzerinden Türkiye'nin dış ticaretine uyarlamak hedeflenmektedir. Buna göre, tedarikçiler tarafından üretilen bir ürün öncelikli olarak, Schenker Lyon Dağıtım Merkezi'ne getirilecektir. İhracat ile ilgili evraklar, blok zinciri ağına yüklenerek şifrelenecektir. Türkiye’ye ulaşan ürün ile ilgili olarak özet beyanın verilmesi, ürünün gümrüklü antrepoya alınması, antrepo ve ithalat beyannamelerinin verilmesi gibi birçok gümrük işlemleri blok zinciri üzerinden gerçekleştirilecektir. Sonuç olarak, diş ticaret süreci ile ilgili bütün evraklar blok zinciri teknolojisi ile korunarak izlenecek ve dijitalleşecektir (Yanık, 2018). Ticaret Bakanı Ruhsar Pekcan, Bakanlığın 2020 yılı içerisinde ihracat alanındaki dijital dönüşüm çalışmalarının devreye alındığı blok zinciri ile ilgili yeni projeler tasarlandığını ifade etmiştir. Türkiye AB, Singapur ve Güney Kore ile dış ticarette veri ve belge paylaşımı için görüşmelere başlamıştır (GÜMRÜK TV, 2020).

\section{Sonuç}

Günümüz rekabet ortamında dünya ülkelerinde Blok Zinciri Teknolojisi’ne olan ilgi gittikçe artmaktadır. Bu teknoloji, dağıtık veri tabanı mimarisi, şeffaf olması, otomatikleşmiş algoritma yapısı, güvenli olması ve eşten eşe iletişim sağlaması gibi avantajları nedeniyle tercih edilmektedir. Blok Zinciri Teknolojisi işletmeler açısından değerlendirildiğinde, bu teknolojinin işletme içinde verilerin doğrulanması, saklanması, karar verme süreçlerinde bürokrasinin azaltılması; müşteriler dâhil olmak üzere, işletme dışından paydaşlarla olan işlemlerde şeffaflık sağlayarak güven oluşturmada etkili olacağı düşünülmektedir. Daha önce güvensizlik sebebiyle ortaklığa girmeyen ulusal ve uluslararası şirketler için yeni işbirliği modelleri üzerinde çalışma ve yeni pazarlara ulaşma fırsatı sunacağına inanılmaktadır. 
Blok Zinciri Teknolojisi bilgilerin yönetimini güven ve şeffaflık avantajları ile kolaylaştırabilir. Blok zincirinin güvenli işlemler yapılabilmesi, verimlilik sağlaması ve daha kısa sürede işlemlerin yapılabilmesi gibi sağlamış olduğu faydalar, kamu kuruluşları için uygulanabilir olmasına yol açarak, pek çok devletin bu alana ilgi duymaya başlamasının neden olmuştur. Hem toplumsal sorunlara yenilikçi çözümler üretme, hem ticari işletmelerin iş süreçlerini değiştirme, hem de devlet kurumlarının hizmet sunma şeklini değiştirme konusunda büyük potansiyele sahip bu teknolojinin yakın gelecekte çok daha yaygınlaşacağı kanaatindeyiz. Halen gelişmekte olan bir teknoloji olduğu için toplumu ve kuruluşları bu teknolojiye adapte etmek oldukça zor ve uzun vadeli bir süreçtir. Bu adapte süreci pilot uygulamalar ile kontrol edilmeli ve hükümet tarafindan desteklenmelidir.

Dünyadaki Blok Zinciri Teknolojisi uygulamalarına bakıldığında, genel olarak finans sektöründe kullanıldığı görülmektedir. Lojistik, gıda ve sağlık sekörleri gibi sektörlerde ve sınırlı da olsa dış ticaret alanında da bu uygulamaya rastlanmaktadır. ABD, İngiltere, $\mathrm{AB}$ ülkeleri, Çin, Japonya, Dubai ve Singapur Blok Zinciri Teknolojisi'ni hemen hemen her alanda kullanmakta olan ve bu teknolojinin kullanımında belirli bir seviyeye gelmiş ülkelerdir. Türkiye ise bu ülkelerin henüz gerisinde kalmaktadır. Türkiye'de ilk defa finans sektöründe Akbank uluslararası para transferinde bu teknolojiyi kullanmaya başlamıştır ve bu teknolojinin kullanımı ve yaygınlaştırılmasına yönelik olarak birtakım girişimler mevcuttur. Dış ticaret alanında ise Türkiye'de henüz bir uygulama olmamakla birlikte, bu teknolojinin kullanımına yönelik projeler yürütülmektedir. Yürütülen bu projeler ile dış ticarete yönelik tüm belgelerin bu teknolojiye adapte edilerek dijitalleşmesi öngörülmektedir. Böylece en kısa sürede, güvenilir bir ağda, hatasız ve düşük maliyetle işlemlerin yapılması Türkiye'nin dış ticareti ve ekonomik büyümesi açısından büyük avantajlar sağlayacaktır. Blok Zinciri Teknolojsi kullanımında, hükümetin destek ve uygulamaları ise Türkiye'nin lider ülkeler arasına girebilmesinde ve rekabet gücünü artırabilmesinde önem arz edecektir.

Türkiye'de Ticaret Bakanlığı tarafından blok zinciri ile ilgili çalışmalara 2016 yılında başlanmıştır. Türkiye ekonomisi açısından dış ticaret işlemlerinde dijital dönüşüm kapsamında bu uygulamanın yüksek katma değer yaratacak önemli araç olarak kullanılacağı düşünülmektedir. Yeni getirilecek sistem ile birlikte dış ticarete yönelik tüm bilgiler blok ziniciri üzerinden paylaşılacak ve ürünlerin ülkeye giriş çıkış sürelerinde önemli ölçüde kısalma söz konusu olacaktır. Bu uygulama ile veriler kaynağından alıcı ülkeye ulaşacağı için, çıkış ülkesindeki verilerin doğruluk teyidi gibi bir iş yükü de ortadan kalkacaktır. Böylece olası vergi kayıplarının da önüne geçilmiş olacaktır.

Blok Zinciri Teknolojisi'nin hızla geliştilmesi için vergi sistemleri içerisinde bu teknolojinin yer bulması gerekmektedir. Bu kapsamda hukuki güvenceye kavuşturulacak bir Blok Zinciri Teknolojisi, hem ulusal hem de uluslararası vergilendirme konusunda yarar sağlayabilecektir. Tüm vergi sistemi için bir çözüm olmasa da yönetimsel yük ve daha az maliyetle vergi toplama ve vergi açığını daraltmak açısından birçok uygulamada kullanılabilir ve sisteme güveni artırabilir.

\section{Kaynakça}

Aktaş, G. (2018). Akıllı Sınır Yaklaşımı Çerçevesinde Blok Zinciri Teknolojisinin Gümrük İşlemlerinde Potansiyel Kullanım Alanları. Gümrük Ticaret Dergisi, 5(14), 18-31.

Bakan, İ. ve Şekkeli, Z.H. (2019). Blok Zincir Teknolojisi ve Tedarik Zinciri Yönetimindeki Uygulamaları. Uluslararası Toplum Araştırmaları Dergisi, 11(18), 2848-2877.

Baktaş, S. (2018). Turkey Blockchaın \& Cryptocurrency Regulatıon. https://medium.com/blocklaw/turkey-blockchaincryptocurrency-regulation-9ef75a63f16b, Erişim Tarihi: 30.02.2020.

Baran, P. (1964). On Distributed Communications: I. Introduction to Distributed Communications Networks, United States Air Force Project Rand.

Barry, C. (2018). How is Cryptocurrency Taxed in Canada?, https://www.moneywehave.com/how-is-cryptocurrency-taxed-in-canada/, Erişim Tarihi: 05.01.2020.

bfmedia (2019). Blockchain Teknolojisinde Kadın Estetiği. https://www.bfmedia.io/haberler/turkiyenin-ilk-blockchain-kadinplatformu-9925.html, Erişim Tarihi: 29.02.2020.

Bitcoin, Bitcoin'e Başlarken, https://bitcoin.org/tr/, Erişim Tarihi: 10.01.2020.

Blockchain Türkiye Platformu (2020). Avrupa Blokzinciri Altyapısı (EBSI) Devreye Girdi. https://bctr.org/avrupa-blokzincirialtyapisi-ebsi-devreye-girdi-14246/, Erişim Tarihi: 28.02.2020.

Boucher, P. (2017). How Blockchain Technology Could Change Our Lives. European Parliament, European Parliamentary Research Service, $1-28$.

coinkolik, Satoshi Nakamoto Kimdir?. https://www.coinkolik.com/bitcoin-rehberi/satoshi-nakamoto-kimdir/, Erişim Tarihi: 02.02.2020

COINTRAL (2019). Ripple Teknolojisi Kullanan Akbank, Blockchain Kullanan İlk Türk Bankası Oldu!. https://cointral.com/tr/rippleteknolojisi-kullanan-akbank-blockchain-kullanan-ilk-turk-bankasi-oldu/, Erişim Tarihi: 19.02.2020.

COINTURK (2018). Kripto Paraların Gelişimi ve Vergisel Konular. https://coin-turk.com/kripto-paralarin-gelisimi-ve-vergiselkonular, Erişim Tarihi: 05.01.2020.

Crosby, M., Nachiappan, M., Pattanayak, P., Verma, S. ve Kalyanaraman, S. (2016). Blockchain Technology: Beyond Bitcoin, Applied Innovation Review, 2, 6-20.

Deloitte, How $\quad$ Blockchain $\quad$ Reshape Trade Finance. https:/www2.deloitte.com/content/dam/Deloitte/global/Documents/grid/trade-finance-placemat.pdf, Date of Access: 01.02.2020.

Demirel, F. (2017). Türkiye'de Blockchain Teknolojisi Üzerinde Çalışan Şirketler. https://webrazzi.com/2017/08/07/turkiyedeblockchain-kullanan-sirketler/, Erişim Tarihi: 15.02.2020.

Erözel Durbilmez, S. ve Yılmaz Türkmen, S. (2019). Blockchain Teknolojisi ve Türkiye Finans Sektöründeki Durumu. Finans Ekonomi ve Sosyal Araştırmalar Dergisi, 4(1), 30-45. 
European Commission (2018). European Countries Join Blockchain Partnership, https://ec.europa.eu/digital-singlemarket/en/news/european-countries-join-blockchain-partnership, Erişim Tarihi: 20.12.2019.

GÜMRÜK TV. (2020). Ticaret Bakanlığı Blockchain Çalışmalarına Başladı. https://www.gumruktv.com.tr/ticaret-bakanligiblockchain-calismalarina-basladi, Erişim Tarihi: 20.01.2020.

Gürsoy, Y. (2016). Dış Ticaret İşlmeleri Yönetimi. Ekin Yayınevi, 10. Baskı, Bursa.

Iansiti, M., Lakhani, K. (2017). The Truth About Blockchain. Harvard Business Reveiw, 95(1), 118-127.

Hackius, N. ve Petersen, M. (2017). Blockchain in Logistics and Supply Chain: Trick or Treat. Hamburg International Conference of Logistics (HICL), 23, October, Hamburg, 1-18.

Hampton, N. (2016). Understanding the Blockchain Hype: Why Much of it is Nothing More Than Snake Oil and Spin. https://www.computerworld.com/article/3472219/understanding-the-blockchain-hype-why-much-of-it-is-nothing-more-than snake-oil-and-spin.html, Erişim Tarihi: 18.02.2020.

Helms, K. (2018). South Korea Found a Way to Tax Cryptocurrencies Under Current Law. https://news.bitcoin.com/south-korea-taxcryptocurrencies-current-law/, Erişim Tarihi: 05.01.2020.

Khandaker, S. (2019). How Blockchain is Transforming Cross-Border Payments. https://www.forbes.com/sites/forbestechcouncil/2019/03/12/how-blockchain-is-transforming-cross-border payments/\#2f42181a7df2, Erișim Tarihi: 15.01.2020.

Lai, K.H. ve Cheng, T. E. (2016). Just in Time Logistics. Routledge and Francis Group. https://books.google.com.tr/books?id=macFDAAAQBAJ\&printsec=frontcover\&dq=just + in + time+lojistic+lai\&hl=tr\&sa=X\&ved $=0$ ahUKEwjA-v2S-vPnAhWxw6YKHcoSDYYQ6AEIKjAA\#v=onepage\&q=just\%20in\%20time\%20lojistic\%20lai\&f=false, Erișim Tarihi: 20.12.2019.

Marr, B. (2018). How Blockchain Will Transform The Supply Chain and Logistics Industry. https://www.forbes.com/sites/bernardmarr/2018/03/23/how-blockchain-will-transform-the-supply-chain-and-logisticsindustry/\#2182bed75fec, Erişim Tarihi: 05.02.2020.

Nakamoto, S. (2008). Bitcoin: a Peer-to-Peer Electronic Cash System. http://bitcoin.org/bitcoin.pdf, Erişim Tarihi: 10.02.2020.

NTV (2018). Türkiye'nin İlk Finansal Blockchain Projesi Hayata Geçti. https://www.ntv.com.tr/ekonomi/turkiyenin-ilk-finansalblockchain-projesi-hayata-gecti,e1ARJIWkM0WFg_1a4wq6HQ, Erişim Tarihi: 20.02.2020.

Ølnesa, S., Ubachtb, J. ve Janssenb. M. (2017). Blockchain in Government: Benefits and Implications of Distributed Ledger Technology for Information Sharing. Government Information Quarterly, 34(3), 355-364.

Özalp, A. (2018). Uluslararası Ticaretin Finansmanı, Prensipleri ve Blockchain, Türkmen Kitabevi, İstanbul.

Özyüksel, S. ve Ekinci, M. (2020). Blok Zinciri Teknolojisinin Diş Ticaret Etkisinin Örnek Projeler Çerçevesinde İncelenmesi. Issletme Ekonomi ve Yönetim Araştırmaları Dergisi, 1, 82-101.

Partz, H. (2018). US Customs and Border Protection to Test Blockchain Shipment Tracking System. https://cointelegraph.com/news/us-customs-and-border-protection-to-test-blockchain-shipment-tracking-system, Erişim Tarihi: 10.02.2020.

Raiborn, C. ve Sivitanides, M. (2015). Accounting Issues Related to Bitcoins. Journal of Corporate Accounting \& Finance, 26(2), 2534.

Peaster, W.M. (2018). Bitcoin, Cryptocurrency and Taxes: What You Need to Know. https://blockonomi.com/cryptocurrency-taxes/, Erişim Tarihi: 05.01.2020.

Potekhina, A. ve Riumkin, I. (2017). Blockchain-a New Accounting Paradigm: Implications for Credit Risk Management, http://www.divaportal.org/smash/get/diva2:1114333/FULLTEXT01.pdf, Erişim Tarihi: 20.12.2019.

Sharma, T.H. (2019). Top 10 Countries Leading Blockchain Technology in the World, https://www.blockchaincouncil.org/blockchain/top-10-countries-leading-blockchain-technology-in-the-world/, Erişim Tarihi: 30.12.2019.

Taş, O. ve Kiani, F . (2018). Blok Zinciri Teknolojisine Yapılan Saldırılar Üzerine bir İnceleme. Bilişim Teknolojileri Dergisi, 11 (4), 369-382.

Türkiye Biliş̧im Vakfı (2019). Blockchain Türkiye, Kişisel Verilerin Korunması Hukuku ve Blokzinciri Teknolojisi Raporu.

Ulukan, G. (2019). Merkez Bankası, Kendi Dijital Parasını Çıkarmayı Planlıyor. https://webrazzi.com/2019/07/09/blockchaintabanli-dijital-merkez-bankasi-parasi/, Erişim Tarihi: 15.02.2020.

Ungan, M.C. (2011). En İyi Tedarik Zinciri Uygulamaları ve Bir Saha Çalışması. Süleyman Demirel Üniversitesi İktisadi ve İdari Bilimler Fakültesi Dergisi, 16(2), 307 - 322.

Usta, A. ve Doğantekin, S. (2017). Blockchain 101. Bankalararası Kart Merkezi Yayınları, Güncellenmiş İkinci Versiyon.

Ünsal, E. ve Kocaoğlu, Ö. (2018). Blok Zinciri Teknolojisi: Kullanım Alanları, Açık Noktaları ve Gelecek Beklentileri, Avrupa Bilim ve Teknoloji Dergisi, 13, 54-64.

Wild, J., Arnold, M. ve Stafford, P. (2015). Technology: Banks Seek the Key to Blockchain. https://www.ft.com/content/eb1f82567b4b-11e5-a1 fe-567b37f80b64, Erişim Tarihi: 20.12.2019.

Xi Xu, B. (2017). Government to Use Blockchain to Prevent Tax Evasion. Tax Notes International, 87(10), 854.

Yanık, (2018). Lyon'dan Manisa'ya Blockchain Köprüsü, http://www.turkishtimedergi.com/teknoloji/turkiyenin-ilk-blockchainprojesi-hayata-geciyor/, Erişim Tarihi: 20.02.2020.

Yavuz, N. (2019). Takasbank Açıkladı: Türkiye'nin İlk Finansal Blockchain Ağı Uygulamaya Geçti. https://www.coinkolik.com/takasbank-aciklama-yapti-turkiyenin-ilk-finansal-blockchain-agi/, Erişim Tarihi: 10.01.2020.

Zheng, Z. ve Xie, S. (2018). Blockchain Challenges and Opportunities: A Survey. Int. J. Web and Grid Services, 14(4), 352-375.

Zuckerman, M.T. (2018). Japanese Crypto Investors to Pay Tax of up to 55 Percent on Profits. https://cointelegraph.com/news/japanese-crypto-investors-to-pay-tax-of-up-to-55-percent-on-profits, Erişim Tarihi: 05.01.2020. 